\title{
Presymptomatic Fibrous Root Decline in Citrus Trees Caused by Huanglongbing and Potential Interaction with Phytophthora spp.
}

\author{
J. H. Graham and E. G. Johnson, University of Florida, Citrus Research and Education Center, Lake Alfred 33850; T. R. Gottwald, \\ USDA-ARS, Fort Pierce, FL 34945; and M. S. Irey, U.S. Sugar Corp., Clewiston, FL 33440
}

\begin{abstract}
Graham, J. H., Johnson, E. G., Gottwald, T. R., and Irey, M. S. 2013. Presymptomatic fibrous root decline in citrus trees caused by huanglongbing and potential interaction with Phytophthora spp. Plant Dis. 97:1195-1199.

Huanglongbing (HLB), associated with 'Candidatus Liberibacter asiaticus', was first detected in Florida in late 2005 and is now widely distributed throughout the commercial citrus-growing regions. In recent seasons, concurrent with freeze and drought episodes, symptomatic HLB-infected trees were much more affected by the extremes of temperature and moisture than trees without HLB. Symptoms exhibited by the stressed trees were excessive leaf loss and premature fruit drop even when HLB-infected trees were managed with good nutritional and irrigation practices recommended to support health of HLBaffected trees. This stress intolerance may be due to a loss of fibrous roots. To assess root status of HLB-infected trees on 'Swingle' citrumelo rootstock (Citrus paradisi $\times$ Poncirus trifoliata), blocks of 2,307 3-year-old 'Hamlin' orange trees and 2,693 4-year-old 'Valencia' orange trees were surveyed visually and with a real-time polymerase chain reaction (PCR) assay to determine ' $\mathrm{Ca}$. L . asiaticus' infection status. The incidence of ' $\mathrm{Ca}$. L. asiaticus'-infected trees (presymptomatic: ' $C a$. L. asiaticus'+, visually negative; and symptomatic: ' $C a$. L.

$88 \%$ for the Valencia block. ' $C a$. L. asiaticus'+ trees had 30 and $37 \%$ lower fibrous root mass density for presymptomatic and symptomatic trees, respectively, compared with ' $\mathrm{Ca}$. L. asiaticus'- trees. In a second survey, 10- to 25-year-old Valencia trees on Swingle citrumelo or 'Carrizo' citrange $(C$. sinensis $(\mathrm{L}$. $) \times P$. trifoliata) rootstock were sampled within 3 to 6 months after identification of visual HLB status as symptomatic (' $\mathrm{Ca}$. L. asiaticus'+, visually positive) or nonsymptomatic (' $\mathrm{Ca}$. L. asiaticus'-, visually negative) in orchards located in the central ridge, south-central, and southwest flatwoods. Pairs of HLB symptomatic and nonsymptomatic trees were evaluated for PCR status, fibrous root mass density, and Phytophthora nicotianae propagules in the rhizosphere soil. ' $\mathrm{Ca}$. L. asiaticus'+ trees had 27 to $40 \%$ lower fibrous root mass density and, in one location, higher $P$. nicotianae per root but Phytophthora populations per cubic centimeter of soil were high on both ' $\mathrm{Ca}$. L. asiaticus'+ and ' $\mathrm{Ca}$. L. asiaticus'- trees. Fibrous root loss from HLB damage interacted with $P$. nicotianae depending on orchard location and time of year.
\end{abstract} asiaticus' + , visually positive) trees was $89 \%$ for the Hamlin block and
Huanglongbing (HLB), greening, and yellow shoot are names for the most devastating citrus disease in the world (9). HLB-like symptoms were first described in India early in the mid-1800s and later throughout Southeast Asia but the disease was not known to be present in the Americas until 2004 and 2005 in Brazil and Florida, respectively. Symptoms of the disease include a distinctive chlorotic mottle on fully expanded leaves (10). Infected shoots are stunted and branches gradually die back as the symptoms appear in other sectors of the tree canopy. Fruit from affected branches may be lopsided and remain green at the stylar end of the fruit. Yield is reduced directly by fruit drop and indirectly by tree decline (2). HLB reduces fruit size, weight, and other fruit quality variables, such as total soluble solids (TSS) content, acidity, and TSS/acidity ratio $(3,5)$. Symptoms of the disease are associated with the presence of bacteria in the phloem of infected trees as determined by polymerase chain reaction (PCR)-based assays $(22,23)$ and, recently, by metagenomic analysis (36). In spite of numerous attempts, including recent ones $(6,30)$, the bacterium is not in prolific culture and is unavailable to fulfill Koch's postulates. Analysis of the $16 \mathrm{~S}$ ribosomal RNA gene of the HLB-associated bacteria has led to the recognition of three species of the 'Candidatus' genus Liberibacter: 'Candidatus Liberibacter asiaticus', 'Ca. L. africanus', and 'Ca. L. americanus' $(23,34)$.

In Florida, HLB associated with ' $\mathrm{Ca}$. L. asiaticus' is now widely distributed throughout the commercial citrus-growing regions. Survey data for 2009 indicated that the cumulative incidence of

Corresponding author: J. H. Graham, E-mail: jhgraham@ufl.edu

Accepted for publication 18 March 2013.

http://dx.doi.org/10.1094/PDIS-01-13-0024-RE

(C) 2013 The American Phytopathological Society infected trees was in the range of 8 to $10 \%$ statewide and, in 2010, had climbed to $18 \%$, which is probably an underestimate (21). Recent 2012 assessments of individual blocks of citrus in various regions of Florida indicate that incidence continues to increase rapidly across all areas of the state (www.crec.ifas.ufl.edu/exten sion/chmas/index.shtml). The highest infection levels occur in southern and east-coast-area orchards, where HLB incidence within individual orchards may be $100 \%$. In the northern and western areas of the state, infection levels in individual orchards are lower. When HLB was first discovered, the citrus industry adopted recommended practices, including control of the insect vector, Diaphorina citri; use of disease-free planting material; and the removal of infected trees to lower the inoculum load. However, as HLB infection increased, many growers abandoned the tree removal component and moved to enhanced nutritional programs (ENPs), which often include foliar applications of phosphite and macro- and micronutrients to support health of HLB-affected trees $(11,20,28,32)$.

During recent episodes of freeze and drought in Florida, symptomatic HLB-infected trees were more adversely affected by extremes of temperature and moisture than trees without HLB. Symptoms of stress (i.e., excessive leaf loss and premature fruit drop) occurred in HLB-infected trees for even those managed with ENPs (11). This stress intolerance may indicate a loss of fibrous root function. Previously, Tatineni et al. (33) detected ' $\mathrm{Ca}$. L. asiaticus' in structural and fibrous roots from infected citrus trees and concluded that the pathogen is translocated systemically throughout the phloem, including the root system. Li et al. (26) detected ' $C a$. L. asiaticus' at $10^{10}$ genomes/g of root tissue for greenhouse and field trees, a titer comparable with or higher than detected in aboveground tissues they sampled. Trivedi et al. (35) reported 2.17 $\times 10^{5}$ to $4.70 \times 10^{6}$ genomes $/ g$ in roots of field trees, a considerably lower titer than detected in leaves $\left(1.98 \times 10^{7}\right.$ to $\left.1.05 \times 10^{8}\right)$. Tatineni et al. (33) concluded that detection of ' $\mathrm{Ca}$. L. asiaticus' in 
roots explains why symptomless trees pruned to the stump level develop HLB symptoms in new growth flushes (27). Hence, the pathogen probably moves bidirectionally in the phloem with the flow of photoassimilate from leaves to sugar-consuming plant organs, including roots, and from roots to shoots when leaves and fruit are produced.

Recent evidence indicates that increasing incidence of HLB in citrus orchards in the presence of Phytophthora nicotianae could have a greater impact on fibrous root health than that caused by the ' $C a$. L. asiaticus' pathogen alone (1). Prior infection of roots by 'Ca. L. asiaticus' accelerates Phytophthora spp. infection and damage to the fibrous roots of potted seedlings and trees. The ' $\mathrm{Ca}$. L. asiaticus'-induced predisposition of roots to P. nicotianae is apparently caused by a greater attraction of swimming zoospores to roots and less resistance to root invasion. The ' $\mathrm{Ca}$. L. asiaticus'Phytophthora interaction promotes higher levels of root damage than ' $C a$. L. asiaticus' or P. nicotianae alone. P. nicotianae and $P$. palmivora affect root health to some extent in most Florida orchards (13). These Phytophthora spp. cause damage to fibrous roots below ground that is difficult to assess directly. Therefore, soil samples are collected from the root zone of trees to measure the populations of the pathogen in the rhizosphere by a quantitative assay in the laboratory. This assay estimates the density of $P$. nicotianae and $P$. palmivora per volume of rhizosphere soil. Based on assays from thousands of samples in relation to health of trees in Florida orchards and fruit yield response to Phytophthora root rot control with fungicides, populations of $P$. nicotianae or $P$. palmivora are considered damaging when counts exceed 10 to 20 propagules per cubic centimeter of rhizosphere soil $(13,19)$.

Citrus rootstocks vary widely in resistance or tolerance to $P$. nicotianae based on the populations they support in the rhizosphere $(4,15)$. When growing in soils amenable for optimal horticultural performance, 'Swingle' citrumelo (Citrus paradisi Macf. $\times$ Poncirus trifoliata (L.) Raf.) is considered tolerant because it does not sustain high populations of $P$. nicotianae and is able to regenerate fibrous roots after infection $(15,24)$. However, in recent decades, Swingle in the east coast and southwest regions has been found to be unsuitable for adverse soils (e.g., high $\mathrm{pH}$, calcareous, and poorly or excessively drained). Under these soil conditions, Swingle is especially susceptible to $P$. nicotianae and $P$. palmivora in the presence of the root weevil Diaprepes abbreviatus. Phytophthora spp. are most destructive when $D$. abbreviatus larvae damage the fibrous and structural roots by direct feeding and a Phytophthora-Diaprepes complex develops $(16,18)$. Normally tolerant rootstocks become highly susceptible because larval feeding causes extensive wounds that break root resistance to infection by Phytophthora spp. This resistance-breaking activity negates the control achieved with phosphite fungicides that act to induce systemic resistance of roots to Phytophthora spp. infection $(16,17)$. Phytophthora survey data from Florida orchards suggest that there is resistance-breaking interaction of ' $\mathrm{Ca}$. L. asiaticus' with Phytophthora spp. but this interaction needs to be fully investigated $(12,13)$.

For the last 25 years in Florida citrus, Syngenta Crop Protection has conducted a statewide soil sampling program in support of Ridomil Gold fungicide, which provides growers with soil propagule counts to estimate the damage that Phytophthora spp. are causing to fibrous roots. Comparison of the survey data for the most recent four seasons, which have been relatively dry, shows a strong trend toward higher incidence of damaging Phytophthora populations coincident with the rise of HLB incidence in Florida citrus orchards $(12,13)$. The survey found an increase in Phytophthora populations not only in the south and the east coast, where HLB incidence is high, but also damaging populations in the central ridge, where high populations of Phytophthora spp. are historically less prevalent.

In experiments with bud-graft-inoculated potted trees, we discovered that ' $\mathrm{Ca}$. L. asiaticus' infects roots well before foliar detection of the bacterium, which results in rapid tree decline by the time HLB symptoms and ' $\mathrm{Ca}$. L. asiaticus' detection occur in the leaves (E. G. Johnson, J. Wu, D. B. Bright, and J. H. Graham, unpublished data). To investigate the relationship between early detection of ' $\mathrm{Ca}$. L. asiaticus' in roots and symptom development, the first objective was to define the timing of root loss with HLB symptom expression in two young tree orchards where prevalence of Phytophthora spp. was unlikely. To determine the extent that damage from ' $\mathrm{Ca}$. L. asiaticus' is associated with Phytophthora spp., the second objective was to compare mature HLB-affected and nonsymptomatic trees on Swingle citrumelo and 'Carrizo' citrange $(C$. sinensis (L.) Osb. $\times$ P. trifoliata) rootstocks, the former relatively tolerant and the latter of intermediate susceptibility to Phytophthora root rot (15).

\section{Materials and Methods}

Young tree survey. In south-central Florida (Highlands County), 2,307 3-year-old trees of 'Hamlin' orange on Swingle citrumelo and 2,693 4-year-old 'Valencia' orange trees on Swingle citrumelo in adjacent orchards were surveyed by PCR to determine ' $\mathrm{Ca}$. L. asiaticus' infection status and by visual HLB symptoms in six replicate blocks of approximately 450 trees in each location. Four of the blocks were located in the corners and two blocks in the center of each orchard. Four fully expanded leaves were collected from each quadrant of the tree and assayed with qPCR primers based on Li et al. (25) using the Southern Gardens Diagnostic Lab (SGDL) protocol for HLB testing, as previously described (21). In the SGDL, a threshold cycle $(\mathrm{Ct})$ value of less than 30 is considered positive and greater than 30 and less than 32 is considered questionable for the presence of ' $\mathrm{Ca}$. L. asiaticus' (22). The incidence of nonsymptomatic (' $\mathrm{Ca}$. L. asiaticus'-, visual symptoms negative), presymptomatic (' $\mathrm{Ca}$. L. asiaticus'+, visual symptoms negative) and symptomatic (' $\mathrm{Ca}$. L. asiaticus'+, visual symptoms positive) trees was determined. For root sampling, 10 trees of each symptom status in each block were sampled by collecting one soil core per tree from the wetted zone under the canopy and combining the 10 cores $(2.4 \mathrm{~cm}$ in diameter by $15 \mathrm{~cm}$ in depth, $67.8 \mathrm{~cm}^{3} /$ core) into one composite sample per block $(n=6)$. Samples were stored in a cooler and immediately returned to the laboratory for processing. After the sample was thoroughly mixed in the bag, a subsample of $50 \mathrm{~cm}^{3}$ was assayed for Phytophthora spp. as previously described (15). Phytophthora CFU detected were expressed as propagules per cubic centimeter of soil volume (15). After removal of $5 \mathrm{~cm}^{3}$ for the Phytophthora spp. plating assay, the remainder of the assay soil was recombined with the composite sample and washed through a mesh screen with 2-mm openings. Citrus fibrous roots recovered on the screen were separated from organic debris, the sample was dried at $70^{\circ} \mathrm{C}$ for $24 \mathrm{~h}$, and the dry weight of the roots was measured. Root mass density per cubic centimeter of soil was calculated by dividing the dry weight of the roots by the volume of soil in the composite sample.

Mature tree survey. To compare Phytophthora spp. propagules and root density for trees on rootstocks tolerant or susceptible to root rot, orchards in three locations of Valencia sweet orange (10 to 25 years old) planted on Swingle citrumelo or Carrizo citrange rootstocks were surveyed for HLB-symptomatic trees twice during 2011. Trees were located in the central ridge (Highlands County), the south-central flatwoods (Desoto County), and the southwest flatwoods (Hendry County) in orchards that were routinely surveyed for symptomatic trees three times per year to identify HLB trees for roguing. Trees were sampled within 3 to 6 months after identification of visual HLB status. In addition, symptomatic leaves were sampled from suspect HLB trees and submitted by the orchard manager to the SGDL for PCR confirmation of the visual survey. Each orchard was sprayed with supplementary applications of potassium phosphite, potassium nitrate, and micronutrients to address concern about HLB effects on tree health $(11,31)$. To compare root mass density and Phytophthora propagule counts for adjacent HLB-symptomatic and nonsymptomatic trees, three pairs in four to five orchards per location were surveyed from April to 
October 2011. To confirm HLB status, leaf samples were collected for PCR assay at SGDL, and soil samples were processed for root mass density and Phytophthora propagules as described above with the following modification: eight soil cores were collected from the wetted zone under each tree and then combined into one sample bag.

Statistical analyses. For each trial, data were subjected to analysis of variance in PROC GLM (SAS Institute). Means were separated using a $t$ test for pairwise comparisons or Student-Newman-Keuls multiple range test at $P \leq 0.05$.

\section{Results}

Young tree survey. To determine the relationship between ' $\mathrm{Ca}$. L. asiaticus' infection and root and canopy symptoms, we compared the status of 3- and 4-year-old trees on Swingle citrumelo rootstock that were nonsymptomatic (' $\mathrm{Ca}$. L. asiaticus'-, visual symptoms negative), presymptomatic (' $\mathrm{Ca}$. L. asiaticus'+, visual symptoms negative), and symptomatic (' $\mathrm{Ca}$. L. asiaticus'+, visual symptoms positive). The incidence of ' $C a$. L. asiaticus'-infected trees (presymptomatic and symptomatic trees) was $89 \%$ for the Hamlin orchard and $88 \%$ for the Valencia orchard (Table 1). In the Hamlin orchard, root mass density for presymptomatic and symptomatic trees was 30 and $37 \%$ lower, respectively, than for nonsymptomatic ' $\mathrm{Ca}$. L. asiaticus'- trees. In the Valencia orchard, root mass density measured for presymptomatic and symptomatic trees was 31 and 38\% lower than for nonsymptomatic trees, respectively. Phytophthora spp. were not detected in either orchard location.

Mature tree survey. HLB-symptomatic Valencia trees on Swingle citrumelo or Carrizo citrange rootstocks and adjacent nonsymptomatic trees were sampled within 3 to 6 months of visual survey to compare Phytophthora propagule and root mass density. P. nicotianae but not $P$. palmivora was detected in each location. Phytophthora populations were high regardless of rootstock or location on ridge versus flatwoods (Table 2). High populations were recovered from both nonsymptomatic and HLB-affected trees and were significantly greater on ' $\mathrm{Ca}$. L. asiaticus' + trees in only a single location and sampling time. In contrast, at all locations and sampling times, root mass density for symptomatic trees was significantly lower than for nonsymptomatic trees. When factoring in the lower root mass density of ' $C a$. L. asiaticus' + trees, $P$. nicotianae per root weight was numerically higher in four of the locations but significantly higher at only one location and sampling time. Overall, Phytophthora populations on all trees sampled, both ' $\mathrm{Ca}$. L. asiaticus'+ and ' $\mathrm{Ca}$. L. asiaticus'-, were 1.3 to 3.9 times higher than the damage threshold of 20 propagules $/ \mathrm{cm}^{3}$ of soil estimated for Florida orchards.

\section{Discussion}

Stress intolerance of HLB-affected trees and unprecedented populations of Phytophthora spp. in a statewide sampling survey led to the investigation of young trees with a low likelihood of Phytophthora infestation and older trees with a high probability of Phytophthora incidence. In each situation, HLB-infected trees were identified as either presymptomatic (young trees) or in the early stages of visual symptom expression (mature trees). Loss of fibrous root mass density for the young presymptomatic trees was approximately $30 \%$ in the absence of detectable HLB symptoms in the tree canopy and Phytophthora spp. detection compared with healthy trees. Presumably, systemic ' $\mathrm{Ca}$. L. asiaticus' infection of roots occurred soon after psyllid transmission into the canopy of the tree, and the bacterium moved to the roots with translocation of carbohydrate for production of root flushes. PCR detection of ' $\mathrm{Ca}$. L. asiaticus' in roots before aboveground symptoms indicates that ' $\mathrm{Ca}$. L. asiaticus' is capable of movement to and multiplication in root tissue and, apparently, causes root damage before disruption of phloem in the leaves (E. G. Johnson, J. Wu, D. B. Bright, and J. H. Graham, unpublished data). In mature orchards, recently detected symptomatic trees sustained 27 to $40 \%$ loss of fibrous root density. In all the orchards sampled, an ENP was practiced as evidenced by the vegetative color and vigor of trees without HLB. This aboveground enhancement of vegetative activity raises the possibility that ENPs stimulate production and quality of fibrous roots, which has been documented in earlier studies to be associated with higher root carbohydrate status and increased Phytophthora spp. activity (7). Another possibility is that root damage or Phytophthora spp. attraction occurs in ' $\mathrm{Ca}$. L. asiaticus'infected trees before visible foliar symptoms have been identified. In experiments with potted trees, ' $\mathrm{Ca}$. L. asiaticus' can infect roots well before foliar detection of ' $\mathrm{Ca}$. L. asiaticus' and lead to rapid tree decline when HLB symptoms and ' $\mathrm{Ca}$. L. asiaticus' detection in foliage occurs (E. G. Johnson, J. Wu, D. B. Bright, and J. H.

Table 1. Huanglongbing (HLB) symptoms and 'Candidatus Liberibacter asiaticus' status of 3-year-old 'Hamlin' and 4-year-old 'Valencia' orange trees on 'Swingle' citrumelo rootstock and the effect on root mass density and percent root loss in two south-central ridge orchards (Highlands County) ${ }^{\mathrm{w}}$

\begin{tabular}{|c|c|c|c|c|c|c|c|}
\hline \multirow[b]{2}{*}{ Condition $^{\mathrm{x}}$} & \multirow[b]{2}{*}{ Status } & \multicolumn{3}{|c|}{ 3-Year-old Hamlin } & \multicolumn{3}{|c|}{ 4-Year-old Valencia } \\
\hline & & Incidence $(\%)^{y}$ & Density $\left(\mathrm{mg} / \mathrm{cm}^{3}\right)^{\mathrm{z}}$ & Root loss (\%) & Incidence $(\%)^{\mathrm{y}}$ & Density $\left(\mathrm{mg} / \mathrm{cm}^{3}\right)^{\mathrm{z}}$ & Root loss (\%) \\
\hline Nonsymptomatic & - & 11 & $0.46 \mathrm{a}$ & & 12 & $0.55 \mathrm{a}$ & \\
\hline Presymptomatic & + & 34 & $0.32 \mathrm{~b}$ & 30 & 42 & $0.38 \mathrm{~b}$ & 31 \\
\hline Symptomatic & + & 55 & $0.29 \mathrm{~b}$ & 37 & 46 & $0.34 \mathrm{~b}$ & 38 \\
\hline
\end{tabular}

${ }^{w}$ Means of six pooled soil samples followed by unlike letters are significantly different according to Student-Newman-Keuls test at $P \leq 0.05$.

${ }^{\mathrm{x}}$ HLB canopy condition.

y Orchard-wide incidence: percentage of 2,307 Hamlin and 2,693 Valencia trees surveyed.

${ }^{\mathrm{z}}$ Root mass density (mg/cm ${ }^{3}$ of soil). All samples had nondetectable Phytophthora spp. soil populations.

Table 2. Phytophthora nicotianae populations, root mass density, and P. nicotianae per root in orchards located in the central ridge (Highlands County), south-central flatwoods (Desoto County) and southwest flatwoods (Hendry County) of Florida for pairs of huanglongbing-symptomatic ('Candidatus Liberibacter asiaticus' + ) and nonsymptomatic ('Ca. L. asiaticus'-) 'Valencia' orange trees on 'Swingle' citrumelo or 'Carrizo' citrange rootstock ${ }^{\mathrm{z}}$

\begin{tabular}{|c|c|c|c|c|c|c|c|c|}
\hline \multirow[b]{2}{*}{ Location } & \multirow[b]{2}{*}{ Scion/rootstock } & \multirow[b]{2}{*}{ Month } & \multicolumn{2}{|c|}{$\begin{array}{c}P . \text { nicotianae } \\
\text { (propagules } / \mathrm{cm}^{3} \text { of soil) }\end{array}$} & \multicolumn{2}{|c|}{$\begin{array}{l}\text { Root mass density } \\
\left(\mathrm{mg} / \mathrm{cm}^{3} \text { of soil }\right)\end{array}$} & \multicolumn{2}{|c|}{$\begin{array}{c}P \text {. nicotianae } \\
\text { (propagules/mg of root) }\end{array}$} \\
\hline & & & - & + & - & + & - & + \\
\hline Highlands County & Valencia/Swingle & April & 63.1 & 38.9 & 0.8 & $0.5 *$ & 78.9 & 77.8 \\
\hline Desoto County & Valencia/Carrizo & May & 92.0 & 65.5 & 2.7 & $1.8 *$ & 34.1 & 36.4 \\
\hline Hendry County & Valencia/Swingle & May & 58.1 & 49.0 & 2.9 & $1.8 *$ & 20.0 & 27.2 \\
\hline Desoto County & Valencia/Carrizo & June & 40.8 & 33.1 & 1.5 & $0.9 *$ & 27.2 & 36.7 \\
\hline Hendry County & Valencia/Swingle & October & 63.7 & 55.1 & 1.5 & $1.0 *$ & 42.3 & $55.1 *$ \\
\hline Highlands County & Valencia/Swingle & October & 34.5 & $18.3 *$ & 1.8 & $1.3^{*}$ & 19.1 & 14.0 \\
\hline
\end{tabular}

${ }^{\mathrm{z}}$ Means ( $n=12$ to 15$)$ for ' $C a$. L. asiaticus' + or ' $C a$. L. asiaticus'- followed by $*$ are significantly different according to paired $t$ test at $P \leq 0.05$. 
Graham, unpublished data). 'Ca. L. asiaticus' infection and reduction in root density appears to be primary and Phytophthora infection that follows may further contribute to the root damage of HLB-affected trees. The magnitude of this damage in orchards as estimated by Phytophthora spp. per root mass density varied with location and time of year. The impact of the Phytophthora spp. interaction on tree yield is currently under evaluation in fungicide trials in Florida orchards.

The order of magnitude of root loss due to HLB and Phytophthora spp. was equal to or greater than $27 \%$ in the two surveys. Previous studies of root density loss due to Phytophthora spp. and the yield response to fungicides was about $10 \%$ for trees on Phytophthora-susceptible rootstocks (29). The relationship for the citrus nematode on a susceptible rootstock was 33\% fibrous root loss and 23\% crop loss for Valencia orange trees (8). In the most comprehensive study of crop loss for HLB, Bassanezi et al. (2) measured 973 trees of early-, mid-, and late-season sweet orange varieties and developed a model for crop loss in relation to visual canopy symptoms. Based on the model, trees in the early stages of canopy decline are predicted to lose approximately $30 \%$ of their crop. Likewise, less-comprehensive assessments of crop loss for trees in Florida indicate a similar magnitude of early crop loss for HLB-affected Hamlin (early-season) and Valencia (late-season) trees which increases with further canopy decline $(14,31,32)$. In the 2012-13 crop season, the fruit drop was exceeded only by previous seasons with either tree-killing freezes or hurricanes. The unprecedented fruit drop is $18 \%$ for early and mid-season varieties and, thus far, 22\% for late-season varieties (http://www.nass.usda.gov/ Statistics_by_State/Florida/Publications/Citrus/cit/2012-13/cit031 3.pdf). We attribute this additional fruit drop to root loss associated with HLB (14).

In HLB-affected trees, phosphite induction of resistance to Phytophthora infection may be providing little protection for roots whose resistance has been degraded by ' $\mathrm{Ca}$. L. asiaticus' infection, as predicted by Phytophthora spp. interaction with root-damaging larvae of Diaprepes root weevil larvae $(16,18)$. Investigation of the effectiveness of control of Phytophthora spp. with fungicides that produce root density and yield responses (29), mefenoxan-based fungicides (i.e., Ridomil Gold), or fosetyl-aluminum (i.e., Aliette) may be warranted as a preventive program in orchards with high prevalence of HLB.

\section{Acknowledgments}

This research was supported by grants from the Florida Citrus Research and Development Foundation and the University of Florida-IFAS Citrus Initiative Program.

\section{Literature Cited}

1. Ann, P.-J., Ko, W.-H., and Su, H.-J. 2004. Interaction between Likubin bacterium and Phytophthora parasitica in citrus hosts. Eur. J. Plant Pathol. 110:1-6.

2. Bassanezi, R. B., Montesino, L. H., Gasparoto, M. C. G., Bergamin Filho, A., and Amorim, L. 2011. Yield loss caused by huanglongbing in different sweet orange cultivars in São Paulo, Brazil. Eur. J. Plant Pathol. 130:577586.

3. Bassanezi, R. B., Montesino, L. H. and Stuchi, E. S. 2009. Effects of huanglongbing on fruit quality of sweet orange cultivars in Brazil. Eur. J. Plant Pathol. 125:565-572.

4. Bright, D. B., Irey, M. S., Baucum, L. E., and Graham, J. H. 2004. Soil, rootstock and climatic factors affect populations of Phytophthora nicotianae in south Florida citrus plantings. Proc. Fla. State Hortic. Soc. 117:167173.

5. Dagulo, L., Danyluk, M. D., Spann, T. M., Valim, M. F., Goodrich-Schneider, R., Sims, C., and Rouseff, R., 2010. Chemical characterization of orange juice from trees infected with citrus greening (Huanglongbing). J. Food Sci. 75:C199-C207.

6. Davis, M. J., Mondal, S. N., Chen, H., Rogers, M. E., and Brlansky, R. H. 2008. Cocultivation of 'Candidatus Liberibacter asiaticus' with actinobacteria from citrus with huanglongbing. Plant Dis. 92:1547-1550.

7. Duncan, L. W., Graham, J. H., and Timmer, L. W. 1993. Seasonal patterns associated with Tylenchulus semipenetrans and Phytophthora parasitica in the citrus rhizosphere. Phytopathology 83:573-581.

8. Duncan, L.W., Mashela, P., Ferguson, J., Graham, J., Abou-Setta, M. M., and El-Morshedy, M. M. 1995. Estimating crop loss in orchards with patches of mature citrus trees infected by Tylenchulus semipenetrans.
Nematropica 25:43-51.

9. Gottwald, T. R. 2010. Current epidemiological understanding of citrus huanglongbing. Annu. Rev. Phytopathol. 48:119-139.

10. Gottwald, T. R., da Graça, J. V., and Bassanezi, R. B. 2007. Citrus huanglongbing: the pathogen and its impact. Plant Health Prog. Online publication. doi:10.1094/PHP-2007-0906-01-RV

11. Gottwald, T. R., Graham, J. H., Irey, M. S., McCollum, T. G., and Wood, B. W. 2012. Inconsequential effect of nutritional treatments on Huanglongbing control, fruit quality, bacterial titer and disease progress. Crop Prot. 36:7382.

12. Graham, J., Gottwald, T., and Irey, M. 2012. Balancing resources for management of root health in HLB-affected groves. Citrus Ind. 93:6-11.

13. Graham, J., Irey, M., and Taylor, J. 2011. Phytophthora damage to roots: A potential contributor to decline of HLB-affected trees. Citrus Ind 92:20-23.

14. Graham, J., Johnson, E., Gottwald, T., and Irey, M. 2013. Integrated management of root health on HLB-affected trees. Citrus Ind. 94:12-14.

15. Graham, J. H. 1995. Root regeneration and tolerance of citrus rootstocks to root rot caused by Phytophthora nicotianae. Phytopathology 85:111117.

16. Graham, J. H. 2002. Larval feeding injury to citrus roots and its relationship to invasion by soil-borne plant pathogens. Pages 51-62 in: Proc. Diaprepes Short Course. S. H. Futch, ed. Univ. Fla. IFAS Coop. Ext. Serv. Lake Alfred.

17. Graham, J. H. 2011. Phosphite for control of Phytophthora diseases in citrus: model for management of Phytophthora species on forest trees? N. Z. J. For. Sci. 41:S49-S56.

18. Graham, J. H., Bright, D. B., and McCoy, C. W. 2003. PhytophthoraDiaprepes weevil complex: Phytophthora spp. relationship with citrus rootstocks. Plant Dis. 87:85-90.

19. Graham, J. H., and Menge, J. A. 1999. Root health: fungal diseases. Pages 126-135 in: Citrus Health Management. L.W. Timmer and L.W. Duncan, eds. American Phytopathological Society, St. Paul, MN.

20. Irey, M. S. 2011. When should a grower with HLB stop removing trees? Page 95 in: Int. Res. Conf. Huanglongbing Proc. Orlando, FL. www. plantmanagementnetwork.org/proceedings/irchlb/2011/

21. Irey, M. S., Gast, T., and Gottwald, T. R. 2006. Comparison of visual assessment and polymerase chain reaction assay testing to estimate the incidence of the huanglongbing pathogen in commercial Florida citrus. Proc Fla. State Hortic. Soc. 119:89-93.

22. Irey, M., Sieburth, P., Brlansky, R., DaGraça, J., Graham, J., Gottwald, T., Hartung, J., Hilf, M., Kunta, M., Manjunath, K., Ling, H., Ramdugu, C. Roberts, P., Rogers, M., Shatters, R., Sun, X., and Wang, N. 2008. Lessons learned from a comparison and evaluation of multiple HLB testing laboratories employing common and different testing methodologies applied to a common set of samples. Page 119 in: Int. Res. Conf. Huanglongbing Proc. Orlando, FL. www.plantmanagementnetwork.org/ proceedings/irchlb/2008/

23. Jagoueix, S., Bové, J. M., and Garnier, M. 1996. PCR detection of the two 'Candidatus Liberibacter species' associated with greening disease of citrus. Mol. Cell. Probes 10:43-50.

24. Kosola, K. R., Eissenstat, D. M., and Graham, J. H. 1995. Root demography of mature citrus trees: the influence of Phytophthora nicotianae. Plant Soil 171:283-288.

25. Li, W., Hartung, J. S., and Levy, L. E. 2006. Quantitative real-time PCR for detection and identification of 'Candidatus' Liberibacter species' associated with citrus huanglongbing. J. Microbiol. Methods 66:104-115.

26. Li, W., Levy, L., and Hartung, J. S. 2009. Quantitative distribution of 'Candidatus Liberibacter asiaticus' in citrus plants with citrus huanglongbing. Phytopathology 99:139-144.

27. Lopes, S. A., Frare, G. F., Yamamoto, P. T., Ayres, A. J., and Barbosa, J C. 2007. Ineffectiveness of pruning to control citrus huanglongbing caused by 'Candidatus Liberibacter americanus'. Eur. J. Plant Pathol. 119:463-468.

28. Pustika, A. B., Subandiyah, S., Holford, P., Beattie, G. A. C., Iwanami, T., and Masaoka Y. 2008. Interaction between plant nutrient and symptom ex pression in mandarin trees infected with the disease Huanglongbing. Aust. Plant Dis. Notes 3:112-115.

29. Sandler, H. A., Timmer, L. W., Graham, J. H., and Zitko, S. E. 1989. Effect of fungicide applications on populations of Phytophthora parasitica and on feeder root densities and fruit yields of citrus trees. Plant Dis. 73:902-906

30. Sechler, A., Schuenzel, E. L., Cooke, P., Donnua, S., Thaveechai, N., Postnikova, E., Stone, A. L., Schneider, W. L., Damsteegt, V. D., and Schaad, N. W. 2009. Cultivation of 'Candidatus Liberibacter asiaticus', ' $\mathrm{Ca}$. L. africanus', and ' $\mathrm{Ca}$. L. americanus' associated with Huanglongbing. Phytopathology 99:480-486.

31. Spann, T. 2010. Overview of Citrus Grower Nutritional Spray Programs for HLB Management. In: Int. Citrus Beverage Conf. Clearwater Beach, FL. http://conference.ifas.ufl.edu/citrus/PresentationPDFs/Friday/Spann.pdf

32. Spann, T., and Schumann, A. 2012. Using good horticultural practices to maintain yield of HLB-affected groves. Citrus Ind. 93:6-11.

33. Tatineni, S., Sagaram, U. S., Gowda, S., Robertson, C. J., Dawson, W. O., Iwanami, T., and Wang, N. 2008. In planta distribution of 'Candidatus Li- 
beribacter asiaticus' as revealed by polymerase chain reaction (PCR) and real-time PCR. Phytopathology 98:592-599.

34. Teixeira, D. C., Saillard, C., Eveillard, S., Danet, J. L., Ayres, A. J., and Bové, J. 2005. 'Candidatus Liberibacter americanus', associated with citrus huanglongbing (greening disease) in Sao Paulo State, Brazil. Int. J. Syst. Evol. Biol. 55:1857-1862.

35. Trivedi, P., Sagaram, U. S., Kim, J. S., Brlansky, R. H., Rogers, M. E., Stelinski, L. L., Oswalt, C., and Wang, N. 2009. Quantification of via- ble 'Candidatus Liberibacter asiaticus' in hosts using quantitative PCR with the aid of ethidium monoazide (EMA). Eur. J. Plant Pathol. 124:553-563.

36. Tyler, H. L., Roesch, L. F. W., Gowda, S., Dawson, W. O., and Triplett, E. W. 2009. Confirmation of the sequence of 'Candidatus Liberibacter asiaticus' and assessment of microbial diversity in huanglongbing-infected citrus phloem using a metagenomic approach. Mol. Plant-Microbe Interact. 22:1624-1634. 